\title{
Carbon Footprint Analysis of Ege University within the Scope of Environmental Sustainability
}

\author{
Sıdıka Tuğçe DAĞLIOĞLU
}

\begin{abstract}
Ege University, Application and Research Center for Environmental Problems, 35040, Bornova, Izmir, Turkey
\end{abstract} ORCID ID: Sıdıka Tuğçe DAĞLIOĞLU: https:// orcid.org/0000-0002-8431-0756

\begin{tabular}{llll}
\hline Received: 20.01 .2021 & Accepted: 15.05 .2021 & Published online: 23.06 .2021 & Issue published: 30.06 .2021
\end{tabular}

\begin{abstract}
Universities play a leading role in promoting sustainability in society. Besides their technical roles, they have important social responsibilities and should be a leader for their stakeholders. Therefore, there is an important need to manage and reduce carbon emissions in universities to ensure environmental sustainability. Ege University (EU) has the vision of being a sustainable campus. In this context, in order to reduce carbon emissions, a carbon footprint study has been carried out primarily to determine carbon emission resources. The life cycle assessment (LCA) tool was used to analyze the Ege University carbon footprint. The study was based on the Greenhouse Gas Protocol Corporate Accounting and Reporting Standard and ISO14064/1-2 standards. In the study, the EU campus was evaluated as the main campus and the medical faculty campus. Total carbon emissions of Ege University in 2016 were analyzed as a total of $40.608 \mathrm{tCO}_{2} \mathrm{e}$ within the Scope 1 , Scope 2, and Scope 3. As a result of the study, it was revealed that $37 \%$ of total emission was caused by constant and mobile combustion, $39 \%$ from electricity usage, and $24 \%$ from travel and staff transportation. In the discussion, it was emphasized that EU should turn to energy conservation and efficiency, awareness activities, and renewable energy resources in its short, medium, and long term plans in order to reduce carbon emissions.
\end{abstract}

Keywords: Carbon management, energy management, carbon emission in campus, reducing carbon emission.

\section{Çevresel Sürdürülebilirlik Kapsamında Ege Üniversitesi Karbon Ayak İzi Analizi}

\begin{abstract}
Öz: Üniversitelerin toplumda sürdürülebilirliği teşvik etmek için teknik rollerinin yanı sıra önemli sosyal sorumlulukları vardır ve paydaşları için bir lider olmalılardır. Sürdürülebilirliği sağlamak için karbon emisyonlarını yönetmek, azaltmak ve üniversitelerde sürdürülebilirliğin teşvik edilmesine önemli bir ihtiyaç vardır. Ege Üniversitesi (EU), sürdürülebilir ve yeşil bir kampüs olma vizyonuna sahiptir. Bu çalışmada, Ege Üniversitesi'nin kurumsal karbon ayak izi hesaplanmıştır. Yaşam döngüsü değerlendirme (YDD) aracı Ege Üniversitesi karbon ayak izini analiz etmek için kullanılmıştır. Çalı̧̧ma, Sera Gazı Protokolü Kurumsal Muhasebe ve Raporlama Standardı ve ISO14064 / 1-2 standartları temel alınarak yapılmıştır. Çalışmada EU kampüsü Merkez Kampüs ve Tip Fakültesi kampüsü olarak değerlendirilmeye alındı. Ege Üniversitesi'nin 2016 yılı toplam karbon salımı Kapsam 1, Kapsam 2 ve Kapsam 3 çerçevesinde toplam 40.608 tCO 2 elarak analiz edildi. Çalışmanın sonucunda $\% 37$ sabit ve mobil yanmalardan, \%39 elektrik kullanımından ve \%24 ise seyahat ve personel ulaşımından kaynaklandığ ortaya konmuştur. Çalışmanın tartışma ve öneriler bölümünde ise EÜ'nün karbon salımını azaltması amacıyla kısa, orta ve uzun vadeli planlarında enerji tasarrufu, bilinçlendirme çalışmaları ve yenilenebilir enerji kaynaklarına yönelmesi gerekliliği vurgulanmıştır.
\end{abstract}

Anahtar kelimeler: Karbon yönetimi; enerji yönetimi; kampüslerde $\mathrm{CO}_{2}$ kaynakları; karbon emisyon azaltımı.

\section{Introduction}

Emission of greenhouse gases, a crucial factor of global warming comes from various type of corporations (Aroonsrimorakot et al., 2013). Consumption of fossil fuels and electricity, transportation, gases used in air conditioning and gases used in laboratory are some activities causing the direct and indirect emissions and need to be managed in environmentally friendly manner in order to reduce the amount of greenhouse gas emissions (GHG) (Aroonsrimorakot et al., 2013). Therefore, many sectors including universities have initiated GHG management systems and focused on reducing carbon emissions (Tatsanawalai, 2015).

Academic sectors have been more conscious and aware of the process and activities which would help reducing GHG after the "Brundlandt Report" and Rio Conference (Gomez et al., 2016). Universities have important roles for sustainable carbon management with their long-short range strategic plans, dense populations, and organizations. A sustainable university campus can be a leader for a sustainable city and change the human behavior (Li et al., 2015).

A sustainable university is an integrated system that should focus on sustainable campus operations such as sustainable transport, sustainable energy management, and etc. (Townsend \& Barrett, 2015). Furthermore, the universities that wish to become leaders in sustainability should consider sustainability issues in their operations, strategic road maps, investment, purchasing, and so on. Additionally, they also need instruments to report and assess their actions and achievements (Gomez et al., 2016). In order to build a sustainable campus, actions should be measured and subsequently reported. Measuring the progress of campus actions can help to show opportunities and threats (Townsend \& Barrett, 2015). For this purpose, carbon footprint (CF) is most widely used and one of the 
important global tools to recognize the impacts on environment (Gomez et al., 2016). To know the carbon footprint of institutions is also important to control greenhouse gases arising from their activities (Üreden \& Özden, 2018). In general, to analyze CF is a way for higher education to monitor sustainability performance and raise awareness among the staff and students. Universities also calculate their $\mathrm{CF}$ to respond to the sustainability needs of the society, to perform a sustainability assessment of their operations, to use as an educational tool with students, and to use for policy development (Lambrechts \& Liedekerke, 2014). In order to make the calculation more accurate and accurate, it should be taken consideration based on a calendar year or fiscal year (Üreden \& Özden, 2018).

Carbon footprint studies have been carried out in many different countries of the world. While these studies were sometimes limited to only one faculty, sometimes the entire campus was evaluated. Alvarez et al. (2014), calculated the carbon footprint (CF) of the School of Forestry Engineering in 2010 and the results showed that the $\mathrm{CF}$ was 2147 tons $\mathrm{CO}_{2} \mathrm{e}$, of which $59.0 \%$ corresponds to scope 3 emissions. Flores et al. (2019) studied the CF of the Cuajimalpa campus of the Autonomous Metropolitan University. The $\mathrm{CF}$ of the campus was calculated as 3000 tons of $\mathrm{CO}_{2}$ equivalent $\left(\mathrm{CO}_{2} \mathrm{e}\right)$. Emissions analysis by activity indicated $51 \%$ for commuting, $24 \%$ for electricity usage, $14 \%$ for academic travel, and $11 \%$ for other activities. Yañez et al. (2020) studied the CF of five campuses in University of Talca. Results show Scope 3, which measures indirect emissions generated by activities like transportation of people, produced the highest contribution of $0.41 \mathrm{tCO}_{2} \mathrm{e}$ per person to the UT's CF in 2016.

The CF was also calculated in national universities. Binboğa \& Ünal (2018) studied the corporate carbon footprint of Manisa Celal Bayar University. They determined that the University emitted 8.954 tons of $\mathrm{CO}_{2}$ (not considering other greenhouse gases) in 2016 and $87.85 \%$ of this was due to electricity consumption. Gökçek et al. (2019) compared the CF of male and female students in Niğde Ömer Halisdemir University and they calculated the CF of male students as $392 \mathrm{~kg}$ /year and CF of female students as $359 \mathrm{~kg} /$ year. The reason that male students have more carbon footprints has been identified as using more electronics and staying at student homes instead of dormitories. The CF was also calculated in Sakarya University, Akdeniz University, and Boğaziçi University. Esentepe Campus of Sakarya University released 12,330 tons of $\mathrm{CO}_{2} \mathrm{e}$. In the study, scope 2, purchased electricity is the most important emission source, followed by emissions from student and employee commuting (Sreng \& Gümrükçüoğlu Yiğit, 2015). In Akdeniz University Health Services Vocational School, the carbon emission from the personnel transportation and electricity consumption was calculated. The annual carbon emission is determined as $98.307 \mathrm{~kg} \mathrm{CO}_{2} \mathrm{e}$ (Yaka et al., 2015).

In this study, the corporate carbon footprint was calculated in order to determine the carbon emission sources of Ege University. The calculations were carried out within the scope of ISO 14064/1 standards. It is considered that determining carbon emission sources within the framework of environmental sustainability steps are very important in determining a roadmap to reduce carbon emissions. It has been observed that the $\mathrm{CF}$ analysis of national universities were mostly on the basis of departments. In this study, it was also aimed to present data of the corporate campus which was located in the city, had a large medical campus, and subway in the concept of holistic approach. On the other hand, in the scope of climate change and the EU Green Deal, it is believed that to deliver data from universities in Turkey is significant to take place among world universities.

\section{Material and Methods}

\subsection{Ege University (EU)}

Ege University (EU) consists of two main campuses covering most of the activities and is located in Bornova/İzmir. There are 66.764 students and 6897 employees (academic and administrative) in the campuses. 14 Faculties, 9 Institutes, 6 High Schools, 1 Conservatory, 8 Vocational Training Schools, 27 Research and Application Centers are divided into two main campuses.

\subsection{Research Method}

Life cycle assessment (LCA) based on the international standard of ISO 14064/1 was used for the purpose of analyzing corporate carbon footprint of EU. This standard specified the requirements for the design, development, management, reporting, and verification of an organization's greenhouse gas inventory. According to the standard, both direct and indirect greenhouse gas emission sources were identified within the context of Scope 1, 2, and 3 (Fig. 1). Direct emissions from constant and mobile consumption of liquefied petroleum gas used on campus are covered in Scope 1. Scope 2 includes indirect emissions by generation and transmission of electricity. Scope 3 covers other indirect emissions and this is an optional category. Scope 3 activities are a consequence of activities of the organization that occur in locations or from sources that are not owned or controlled by the university (Fig. 1) (Yañez et al., 2020).

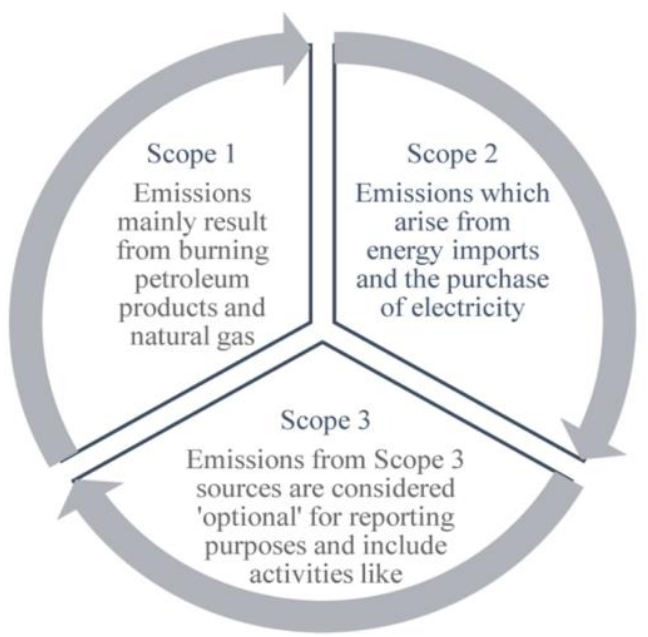

Figure 1. Direct and indirect emissions sources

The basis of the study was determining $\mathrm{CO}_{2}$ equivalent of each activity. The Greenhouse Gas Protocol, Corporate Accounting and Reporting Standard, and ISO14064/1-2 standards were used for analysis.

In the EU corporate carbon footprint calculation study, the data obtained from the campus were multiplied 
with the relevant emission factors and the emission data according to the activities were obtained in terms of carbon dioxide equivalent $\left(\mathrm{CO}_{2} \mathrm{e}\right)$. The $\mathrm{CO}_{2} \mathrm{e}$ was obtained by multiplying the mass of the supplied greenhouse gas and its global warming potential (for methane 28 times, for $\mathrm{N}_{2} \mathrm{O} 256$ times). The greenhouse gases were determined as carbon dioxide $\left(\mathrm{CO}_{2}\right)$, nitrous oxide $\left(\mathrm{N}_{2} \mathrm{O}\right)$, methane $\left(\mathrm{CH}_{4}\right)$, hydrofluorocarbons (HFC), sulfur hexafluoride $\left(\mathrm{SF}_{6}\right)$, perfluorocarbons (PFC), and refrigerant gases in the Kyoto Protocol and in the study, global warming potential of GHGs were used as Intergovernmental Panel on Climate Change (IPCC, Climate Change-5th Assessment Report (2013) 1 and DEFRA2 British Government Ministry of Environment published guide.

\subsection{Data collection}

For the base year 2016, all data were collected from each academic unit (faculties, research centers, etc.) and administrative institutions. Fuel consumption used for heat production, generator usage, vehicle fuel consumption, gas purchased for air conditioner and cooling systems were collected as Scope 1 emissions. The annual amount of natural gas $\left(\mathrm{Sm}^{3}\right)$ and fuel consumption in generators were separated for EU medical and main campus. Emission factors were provided from the "Greenhouse Gas Calculation Inventory Manual" published by the IPCC in 2006 (Table 1) (GHG Inventory Manual, www.climate.emb.gov). In order to calculate emissions from the purchased electricity (Scope 2), it is necessary to know the value per $\mathrm{kWh}$ electricity generation by country. In Turkey, the amount of emissions released during electricity generation is $0,496 \mathrm{~kg} \mathrm{CO}_{2} \mathrm{e} /$ $\mathrm{kWh}$. Domestic and international flight data were used for Scope 3. Emissions from staff transportation were also calculated within Scope 3. 3 types of transportation were taken into consideration in staff transportation calculated within the Scope 3. EU private vehicle entry was 15\% according to the information obtained from the security data. The arrival of other staff to the campus was considered as $35 \%$ by subway (rail, subway, GHG transport tool) and $65 \%$ by bus and minibus (road, local bus, GHG transport tool) according to Izmir public transportation rates (Pektaş, 2017; www.ghgprotocol.org). The distance to the campus was accepted as 25 kilometers (between Konak-Bornova, round-trip) for all transportation types.

Greenhouse gas potentials were taken from DEFRA Guide (UK) (Defra Guide, www.gov.uk). All data are given in Table 2.

\section{Results}

Greenhouse gas emissions by Ege University in the year 2016 are shown in Table 3. The total greenhouse gas emissions that resulted from the activities of Ege University in the year 2016 are equal to $40.608 \mathrm{tCO}_{2} \mathrm{e}$ as presented in Table 3 and Figure 2 shows the ratio of GHG emissions. The total carbon footprint of the EU Main Campus in 2016 was 11.897 t CO $\mathrm{CO}_{2}$ within Scope 1 and 2. GHG caused by air conditioning and refrigerant leaks took the 3\% share in Scope 1. Emissions caused by the use of vehicles (mobile combustion) connected to the university the emissions caused by these activities covered the part of $1 \%$. P-10, acetylene and $\mathrm{CO}_{2}$ gases used in laboratory studies had $1 \%$ effect on total greenhouse gas emissions. According to the greenhouse gas resources used in the carbon footprint calculation within the Medical Campus, $46 \%$ of the 19,132 tons of $\mathrm{CO}_{2} \mathrm{e}$ carbon footprint was caused by natural gas used in heating activities. Emissions from indirectly purchased electricity accounted for $49 \%$. In addition, emissions of refrigerant gas R410 and gasoline used in vehicles were calculated less than $5 \%$. The contribution of other refrigerant gases such as R407 and $\mathrm{R} 134 \mathrm{a}$ to the total greenhouse gas emission was less than $1 \% . \mathrm{CO}_{2}$ used in medical activities made $1 \%$ effect on total greenhouse gas emissions.

It is demonstrated that the staff transportation within Scope 3 had an important ratio of $24 \%$ within the total carbon emission of the EU. $15 \%$ private vehicle use caused $73 \%$ of transportation emissions. When considering that $35 \%$ of staff come by subway and $65 \%$ by road; emission rates for transportation were analyzed as $11 \%$ and $16 \%$, respectively.

Scope 1 -Scope 2 - Scope 3

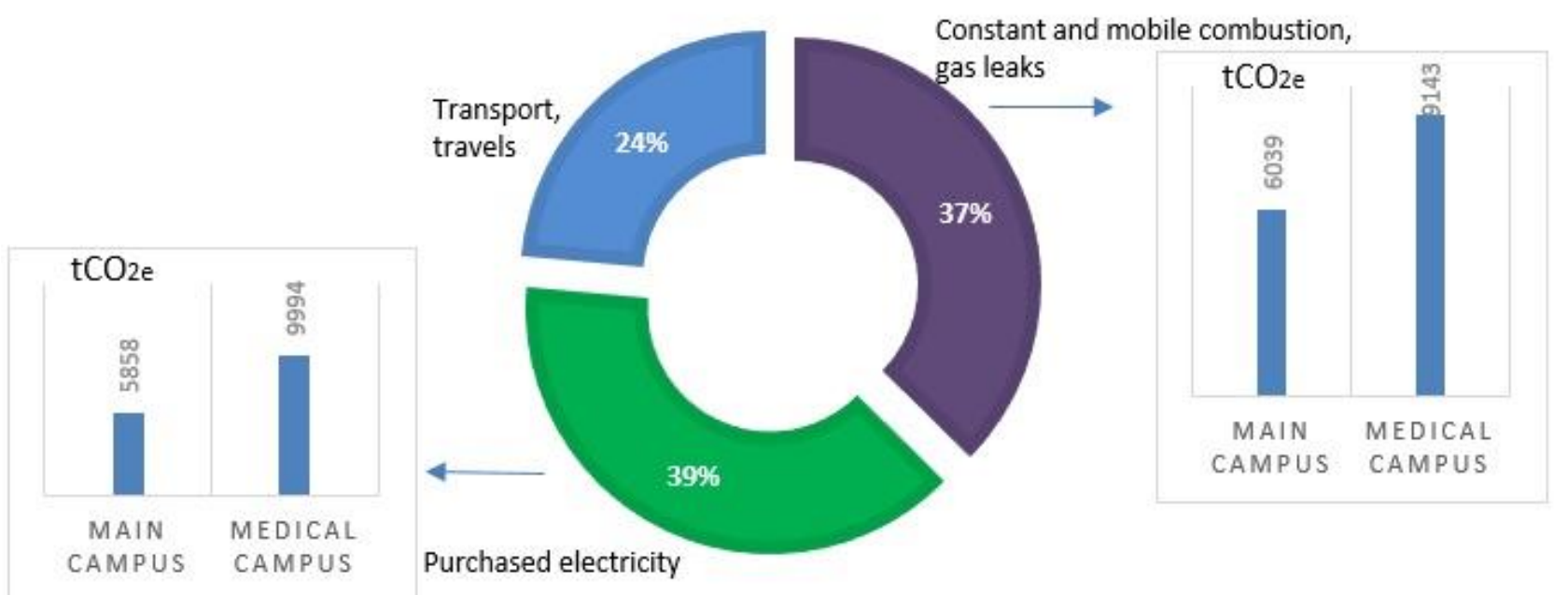

Figure 2. EU Carbon Footprint Analyses- GHG sources 
Table 1. Emission factors of greenhouse gases

\begin{tabular}{|c|c|c|c|c|c|c|c|c|}
\hline \multirow{2}{*}{$\begin{array}{l}\text { Operation } \\
\text { (constant combustion) }\end{array}$} & \multicolumn{3}{|c|}{ Emission Factor (kg/TJ) } & \multirow[t]{2}{*}{$\begin{array}{l}\text { Operation } \\
\text { (constant combustion) }\end{array}$} & \multicolumn{4}{|c|}{ Emission Factor $(\mathrm{kg} / \mathrm{TJ})$} \\
\hline & $\mathrm{CO}_{2}$ & $\mathrm{CH}_{4}$ & $\mathrm{~N}_{2} \mathrm{O}$ & & & $\mathrm{CO}_{2}$ & $\mathrm{CH}_{4}$ & $\mathrm{~N}_{2} \mathrm{O}$ \\
\hline Heating (Natural Gas) & 56.100 & 5 & 0.1 & \multirow{2}{*}{$\begin{array}{l}\text { Off-road vehicles } \\
\text { (tractor, lawnmower, etc.) }\end{array}$} & Gasoline & 69.300 & 25 & 8 \\
\hline Generator (Diesel) & 74.100 & 10 & 0.6 & & Diesel & 74.100 & 4.15 & 28.6 \\
\hline \multirow[t]{3}{*}{ LPG } & 63.100 & 5 & 0.1 & Vehicle use & Gasoline & 69.300 & 25 & 8 \\
\hline & & & & & Diesel & 74.100 & 3.9 & 3.9 \\
\hline & & & & Boat use & Diesel oil & 74.100 & 7 & 3 \\
\hline
\end{tabular}

Table 2. Emission sources of EU

\begin{tabular}{|c|c|c|c|c|c|c|}
\hline & Operation & Emission Sources & Total & Unit & Main Campus & Medical Campus \\
\hline 1 & Boilers & Natural gas & 7.141 .562 & $\mathrm{Sm} 3$ & 2.840 .814 & 4.300 .748 \\
\hline 2 & Generator & Diesel & 43.500 & $\mathrm{~L}$ & 7.500 & 36.000 \\
\hline 3 & LPG & Natural gas & 2.497 & $\mathrm{~m} 3$ & 2.497 & - \\
\hline 4 & Industrial and domestic energy & Purchased electricity & 31.743 .251 & $\mathrm{kWh}$ & 11.730 .129 & 20.013.122 \\
\hline \multirow[t]{2}{*}{5} & Vehicle use (tractor, lawnmower) off-road & Gasoline & 34.125 & $\mathrm{~L}$ & 34.125 & - \\
\hline & & Diesel & 2.013 & $\mathrm{~L}$ & 2013 & - \\
\hline \multirow[t]{2}{*}{6} & Vehicle use & Gasoline & 4.814 & $\mathrm{~L}$ & 4.814 & \\
\hline & & Diesel & 16.063 & $\mathrm{~L}$ & 2.713 & 13.350 \\
\hline \multirow[t]{2}{*}{7} & Truck, transport vehicle & Gasoline & 37.583 & $\mathrm{~L}$ & 10.883 & 26.700 \\
\hline & & Diesel & 1.675 & $\mathrm{~L}$ & 1.675 & - \\
\hline 8 & Boat & Diesel & 1.000 & $\mathrm{~L}$ & 1.000 & - \\
\hline \multirow[t]{4}{*}{9} & Air conditioner gas leakage & R407 & 300 & $\mathrm{~kg}$ & 0,01 & 300 \\
\hline & & R410 & 36 & $\mathrm{~kg}$ & 18 & 18 \\
\hline & & R134A & 27 & $\mathrm{~kg}$ & 27 & - \\
\hline & & $\mathrm{R} 22$ & 2.044 & $\mathrm{~kg}$ & 234 & 1.810 \\
\hline \multirow[t]{4}{*}{10} & Laboratory gas & $\mathrm{N} 2 \mathrm{O}$ & 14 & $\mathrm{~kg}$ & 14 & - \\
\hline & & Acetylene & 92 & $\mathrm{~kg}$ & 46 & 46 \\
\hline & & $\mathrm{CO} 2$ & 5.316 & $\mathrm{~kg}$ & 869 & 4.447 \\
\hline & & P-10 & 2.863 & $\mathrm{~kg}$ & 2.863 & - \\
\hline
\end{tabular}

Table 3. GHG emissions and sources

\begin{tabular}{|c|c|c|c|}
\hline Scope & Operation & $\begin{array}{c}\text { Main Campus } \\
\text { Carbon Footprint }\left(\mathrm{tCO}_{2} \mathrm{e}\right)\end{array}$ & $\begin{array}{c}\text { Medical Campus } \\
\text { Carbon Footprint }\left(\mathrm{tCO}_{2} \mathrm{e}\right)\end{array}$ \\
\hline \multirow[t]{10}{*}{ Scope 1} & Constant combustion (natural gas) & 5.512 & 8.345 \\
\hline & Constant combustion (diesel) & 19.8 & 27.7 \\
\hline & Constant combustion (LPG) & 7.23 & - \\
\hline & Mobile combustion (diesel) & 23.6 & 35.5 \\
\hline & Mobile combustion (gasoline) & 135 & 61.5 \\
\hline & Cooling / air conditioner gas leaks \& leak gases- R410 & 221 & 85.5 \\
\hline & Cooling / air conditioner gas leaks \& leak gases- R407 & 0.0211 & 583 \\
\hline & Cooling / air conditioner gas leaks \& leak gases- R134a & 35.1 & - \\
\hline & Other gases (Laboratories) - $\mathrm{CO}_{2}$ & 85.0 & 4.60 \\
\hline & TOTAL & 6.039 & 9.143 \\
\hline \multirow[t]{3}{*}{ Scope 2} & Purchased electricity & 5.858 & 9.994 \\
\hline & TOTAL & 5.858 & 9.994 \\
\hline & TOTAL (SCOPE 1 + SCOPE 2) & 11.897 & 19.136 \\
\hline \multirow[t]{5}{*}{ Scope 3} & Travels & 315 & \\
\hline & *Staff transportation (private vehicle) & 6.752 & \\
\hline & *Staff transportation (rail-subway) & 996 & \\
\hline & *Staff transportation (road) & 1.512 & \\
\hline & TOTAL (SCOPE 1 + SCOPE 2+SCOPE3) & 21.472 & 19.136 \\
\hline
\end{tabular}

* This calculation includes the total emission of medical and main campus staffs. The distance between the medical and main campus is not taken into account

The results clearly highlighted that purchased electricity in the context of Scope 2 was the highest GHG emission source with $39 \%$. The Medical campus with
19.132 $\mathrm{tCO}_{2} \mathrm{e}$ GHG emission should be taken into consideration primarily. The second highest GHG emissions result from constant combustion (burning 
natural gas, fuel oil, etc.) with $37 \%$. Emissions from mobile combustions and leakages are approximately $4 \%$ for 2016 year of Ege University and $0,55 \mathrm{tCO}_{2} \mathrm{e}$ carbon were emitted per capita.

\section{Discussion}

In this section, the results are compared with the other studies and the recommendations to reduce the carbon footprint are discussed.

In comparison to the universities in Europe, Asia, and America, it is clear that universities in Turkey has much less emissions (Fig. 3) (Boğaziçi University Report, 2014, Tokio University Report, 2012; Larsen et al., 2013; Hong Kong University Report, 2013; Cambridge University Report, 2013; Cape Town University Report, 2014; California University Report, 2007; Meida et al., 2013; Queen University Report, 2015; College Cork, 2012; Nottingham University Report, 2015). However, it could be seen that energy consumption was the most significant emission factor which should be taken into consideration in universities all over the world (Aroonsrimorakot et al., 2013, Tatsanawalai, 2015, Gomez et al., 2016, Li et al., 2015, Townsend \& Barrett 2015). Yañez et al. (2020) compared the carbon footprints of different universities from different parts of the world such as the USA, China, and Europe. In the study, it was seen that the highest carbon footprint was in the USA. In different universities of the USA, their footprints per student varied between 7.9 and $36.4 \mathrm{tCO}_{2} \mathrm{e}$. The $\mathrm{CF}$ was determined as $4.6 \mathrm{tCO}_{2} \mathrm{e}$ per student and 16.7 per employee $\mathrm{tCO}_{2} \mathrm{e}$ for Norway. In Spain, $0.31 \mathrm{tCO}_{2} \mathrm{e}$ was calculated per student within only Scope 1 and 2 and $3.84 \mathrm{tCO}_{2} \mathrm{e}$ was analysed in Tongji
University from China. In Ege University study $0.55 \mathrm{tCO}_{2} \mathrm{e}$ was calculated per capita. The USA universities have the highest CF on the basis of countries, it is in parallel with the fact that the USA has one of the highest CF's with 16 tCO2e per capita. While this value is 6-7 $\mathrm{tCO}_{2} \mathrm{e}$ for China and the European Union, it varies between 0.3 and 8 in the underdeveloped countries of Africa (www.data.worldbank.com). With regard to other universities in Turkey, it was seen that the analysis were carried out only for specific buildings; Boğaziçi, Sakarya, and Akdeniz universities reported limited case studies in their campuses. While GHG emissions from purchased electricity were major reasons for both Sakarya and Akdeniz universities, natural gas burning was the highest GHG emissions sources for Boğaziçi University (Yaka et al., 2015; Sreng \& Gümrükçüoğlu Yiğit, 2017; Boğaziçi University Report, 2014). Binboğa \& Ünal (2018) studied the corporate carbon footprint of Manisa Celal Bayar University. As a result of the calculation, they determined that the University emitted 8.954 tons of $\mathrm{CO}_{2}$ (not considering other greenhouse gases) in 2016 and $87.85 \%$ of this was due to electricity consumption. While purchased electricity in Scope 2 appeared as a hot spot in national universities, it was observed that Scope 3 and transportation were hot spots in studies in different countries. Alvarez et al. (2014), Flores et al. (2019), and Yañez et al. (2020) reported that transportation and commuting in Scope 3 were crucial emission factors. Therefore, it was found that some points should be paid attention to make comparisons. In order to make an accurate comparison, it should be observed which method is used in the study, especially which parameters are in operation in Scope 3 which is optional.

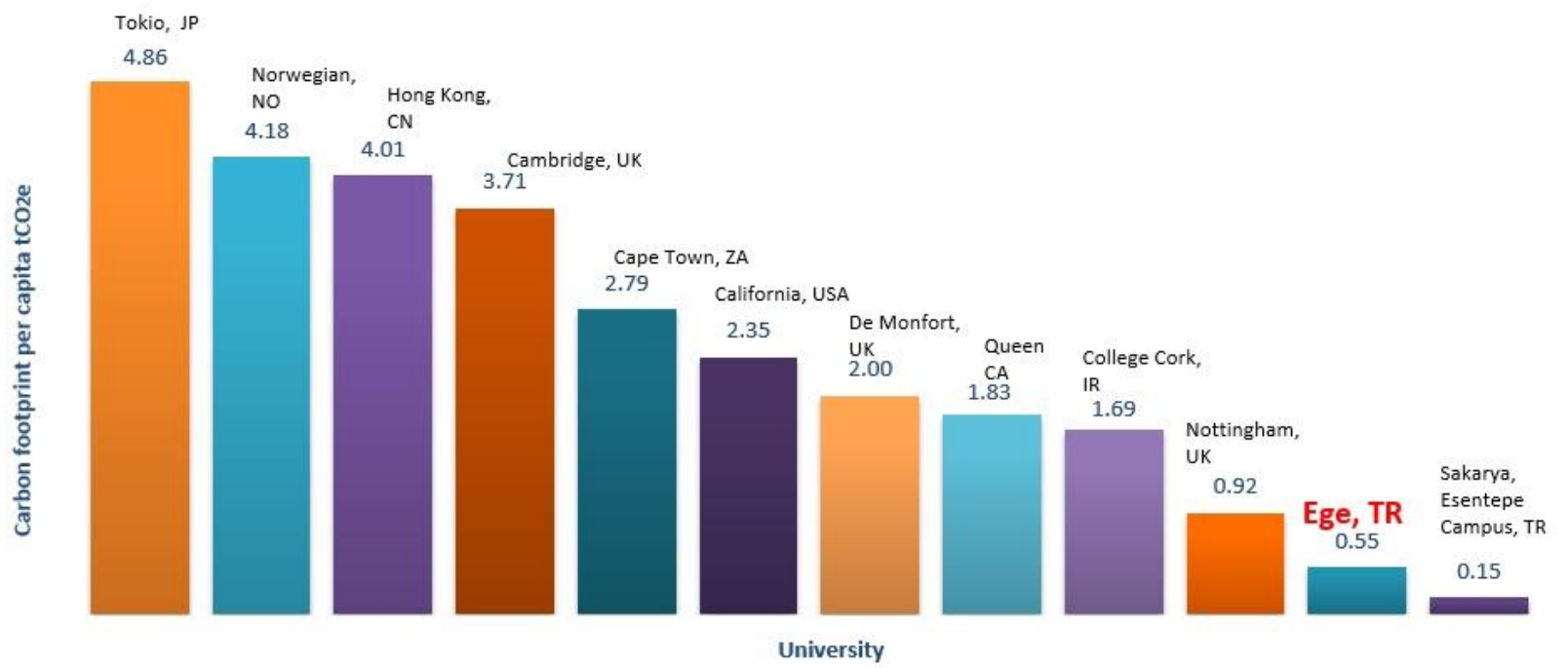

Figure 3. Carbon footprint per capita in different universities

In this study, the hot spot of Ege University was determined as the electricity consumption of the Medical Campus. When Scope 1 and 2 considered, the emission of the Medical Campus had an emission rate of $61 \%$. In the whole campus, the first emission source was determined as electricity consumption. On the other hand, staff transportation accounted for $24 \%$ of all emissions. The crucial point to note here is that only $15 \%$ of the staffs with their private vehicles occupied $73 \%$ of the transportation emissions.
These results showed the important emission sources of Ege University within the scope of determining the hot spots, which was the main purpose of the study. As the next step, recommendations for Ege University were researched. In this context, in order to monitor the sustainability steps of the campus, the globally accepted green measurement rankings and the recommendations of the United Nations were examined. There are many different evaluation methods and green campus tools in the world for universities to make their own situation 
evaluations. The Greenmetric from Indonesian Universities is one of these evaluation methods which Ege University has applied. Greenmetric ranks universities by scoring on energy, water, transportation, infrastructure, education, and waste under environmental sustainability titles. In fact, this ranking systems provides an important step in evaluating the scores of universities within themselves and being a road map for sustainability steps. Carbon footprint is also included in these evaluations under the heading of energy. In this system, which Ege University has applied since 2016, the heading of "energy" and the necessity to reduce the carbon footprint stand out. At this point, lower scores obtained from the energy category also support the transition from fossil fuels to cleaner energy sources and the need to use energy efficient devices.

One of the other important resources for universities to become more sustainable is the Greening Universities Toolkit prepared by the United Nations. The toolkit offers 3 main topics to universities in order to reduce their carbon footprint. Energy conservation is one of the topic which includes staff energy conservation training; energy awareness programs, such as campus posters; improved space utilization; and energy efficiency standards for new construction and refurbishments (www.unep.org). At this point, Ege University should reach all students and staff to raise awareness in energy saving, just like in the Zero Waste System of EU. These trainings will also provide an important step towards obtaining ISO: 50001 Energy Management Certificate. In Turkey, there were not yet ISO: 50001 Certification in public universities but Nişantaşı and Yaşar University have been awarded ISO: 50001 Certificate. In Ondokuz Mayıs University, Energy Management Directive has been prepared within the scope of energy studies and put into practice as an accepted directive (OMU, 2020). According to Yañez et al. (2020) adopting an energy management system such as ISO 50001 could provide $6 \%$ energy consumption and it would mean $2.1 \%$ total GHG emission reduction. Ege University should prioritize energy efficiency for the Medical Campus among short-term goals to reduce GHG emission. Besides, energy efficiency studies of buildings should be carried out for the whole campus to get ISO: 50001 certificate.

According to Tatsanawalai (2015), the most important method for reduced GHG is to change the behavior through focusing on carbon footprint. Gökçek et al. (2019) investigated the relationship between behavior patterns of students and carbon footprint at Niğde Ömer Halisdemir University. It was observed that the highest carbon footprint was found in the medical faculty students with an average of $433 \mathrm{~kg} \mathrm{CO}_{2}$ / year. Also, in this study, it was determined that male students had higher carbon footprint. The reason for this was determined to be staying at student houses rather than dormitories and using electronic devices more than females (Gökçek et al., 2019). Therefore, educational programs in universities have enormous potential to reduce the power consumption of students and staff. Projects and courses for changing behaviors, reducing fossil fuels should be supported by the university. Media organs of the university and the university webpage could be used for communication and awareness purposes.

The second proposal of the United Nations Greening
Universities Toolkit is energy efficiency. The steps include building retrofitting; heating; ventilation and airconditioning; and periodic recommissioning and building tuning to optimize energy efficiency. This steps need technical operation and budget. It will be necessary to make energy efficiency analyses in the buildings and to create a road map according to the results. The current status of Karamanoğlu Mehmetbey University (KMU) in terms of energy was revealed and its energy efficiency potential was examined. The energy consumption values used in the buildings belonging to the KMU campus were determined, regular measurements were taken using appropriate devices (thermal camera, flue gas analyzer, ultrasonic flowmeter, etc.) at energy consumption points, and efficiency increasing projects were proposed at these points. According to the results, it is determined that the energy consumption value of the university in 2016 reached 1422 tons of equivalent oil (TEP) and has an energy saving potential of up to $18 \%$ (Rüşen et, 2018). Üreden \& Özden (2018) suggested that the external insulation of the buildings could reduce the emission due to heat. Providing the building ventilation over the heating system especially in winter months would prevent sudden temperature drops in the building and would not cause unnecessary carbon emissions.

Biomass of the campus is also important for carbon absorption potential. One ton of carbon storage in a tree represents the removal of $3.67 \mathrm{t}$ of carbon from the atmosphere and the release of $2.67 \mathrm{t}$ of oxygen back into the atmosphere (Ugle et al., 2010). The carbon storage capacity of different species was reported in Erdoğan et al. (2020) study (www.tmmobizmir.org). In this context, it is recommended to reveal the flora biodiversity in the campus and analyze the carbon storage capacities on the basis of species. In addition, increasing the biomass of the campus will reduce GHG emissions.

Private vehicle use accounted for the largest share of transport emissions. In this context, staff buses between campus and residents are offered to stop the use of private vehicles. It is recommended that the staff in units that are far away from the campus entrance such as Faculty of Engineering, Ege Vocational School, Faculty of Education, are directed to low-priced services provided by the management of the EU. On the other hand, to provide a safe bicycle path to the campus entrance for staff and students from districts such as Bornova and Bayraklı can also reduce the private vehicle use.

Another important step is to turn to renewable energy sources and installation of solar cells, wind, biomass, and other renewable energy systems. As mentioned before; EU, which was founded in 1955, is not in a position where all these transformations can happen at once with its 90 buildings and 70.000 population. Therefore, as a result of this study it is suggested that EU should determine and follow-up of numerical targets to reduce its carbon footprint within the short, medium, and long term periods.

In terms of accelerating the efforts of universities to reduce GHG emissions, universities should be supported financially. TUBITAK, the Ministry of Environment and Urbanization, the Ministry of Development, and the Ministry of Energy can encourage the national universities with grant applications. These grants will support the 
GHG reduction targets of Turkey by 2030 and the EU Green Deal targets.

\section{Conclusion}

In conclusion, GHG emissions of EU in 2016 were 40.068 $\mathrm{tCO}_{2} \mathrm{e}$. These results suggest that "Energy Policy and Action Plan" should be urgently prepared by Ege University. Use of fossil fuels and purchased electricity and use of constant combustion sources which come from burning of fossil fuels were main sources and should be reduced. In order to realize an efficient energy management system in EU, energy-saving technologies and/or energy saving campaigns should be put in practice. The summary of recommendations is;

- Energy efficiency studies, with priority in Medical Faculty,

- To provide staff transportation service to campus and safety bicycle way to campus,

- To increase education, courses, activities to raise awareness,

- To start using renewable energy sources at a certain rate,

- To increase biomass in the campus for storing the carbon.

Universities need to become more proactive in sustainable development actions for helping societies to become more sustainable. The most successful universities on the way to becoming a green campus will be universities that accept these changes and take action. Although there are carbon footprint studies in some universities in our country, it is necessary to spread these studies throughout the country and to implement energy policies aimed at reducing the carbon footprint.

Acknowledgements: The author wishes to thank Ege University for the financial support of this study under the grant no 16/CSUAM/003.

Ethics committee approval: Ethics committee approval is not required for this study.

Conflict of interest: The author declares that there is no conflict of interest.

\section{References}

Alvarez, S., Blanquer, M., \& Rubio, A. (2014). Carbon footprint using the Compound Method based on Financial Accounts. The case of the School of Forestry Engineering, Technical University of Madrid. Journal of Cleaner Production, 66, 224-232. https://doi.org/10.1016/i.jclepro.2013.11.050

Aroonsrimorakot, S., Yuwaree, C., Arunlertaree, C., Hutajareorn, R., \& Buadit, T. (2013). Carbon footprint of faculty of environment and resource studies, Mahidol University, Salaya Campus, Thailand. APCBEE Procedia, 175-180. https://doi.org/10.1016/j.apcbee.2013.05.031

Binboğa, G., \& Ünal, A. (2018). Sürdürülebilirlik Ekseninde Manisa Celal Bayar Üniversitesi'nin Karbon Ayak İzinin Hesaplanmasına Yönelik Bir Araştırma. Uluslararası İktisadi ve İdari İncelemeler Dergisi, 21, 187-202. https://doi.org/10.18092/ulikidince.323532

Boğaziçi University Carbon Footprint Studies. (2014). Retrieved from http://www.boun.edu.tr/tr (Date accessed: 2020, November 25).

California University Carbon Footprint Studies. (2007). Retrieved from https://www.sustainability.caltech.edu/documents/75-stanislava_final_draft.pdf (Date accessed: 2020, November 25)

Cambridge University Carbon Footprint Studies. (2013). Retrieved from https://www.environment.admin.cam.ac.uk/what-are-we- doing/carbon/scope-1-2-and-3-emissions (Date accessed: 2020, November 25)

Cape Town University Carbon Footprint Studies. (2014). Retrieved from https://www.uct.ac.za/sites/default/files/image_tool/images/328/ explore/sustainability/reports/UCT_Carbon_Footprint_Report_2014. pdf (Date accessed: 2020, November 25)

College Cork University Carbon Footprint Studies. (2012). Retrieved from https://www.ucc.ie/en/media/support/buildingsandestates/energy Lreports/UCCCarbonFootprint2011-12BE1310-BR-B-002.pdf (Date accessed: 2020, November 25)

DEFRA Guide. Retrieved from https:// www.gov.uk/government/publications/greenhouse-gasreporting-conversion-factors-2017 (Date accessed: 2020, December 12)

Erdoğan, N., Ekşi, I., Çavdar, B., \& Kaylı A. (2020). Kültürpark'ın Karbon Tutma Potansiyeli. Retrieved from http://www.tmmobizmir.org/wpcontent/uploads/2020/12/Kent_E kosistemine_Katkilari_pdf (Date accessed: 2021, March 12)

Flores, R., Ramírez, R., \& Ortiz, I. (2019). The carbon footprint of a public university campus in Mexico City. Carbon Management, 10(5), 501-511. https://doi.org/10.1080/17583004.2019.1642042

Gökçek, Ö.B., Bozdağ, A., \& Demirbağ, H. (2019). Niğde Ömer Halisdemir Üniversitesi Örneğinde Karbon Ayak İzinin Belirlenmesi. Niğde Ömer Halisdemir Üniversitesi Mühendislik Bilimleri Dergisi, 8(2), 721-730. https://doi.org/10.28948/ngumuh.514438

Gomez, N., Angeles Cadarso, M., \& Monsalve, F. (2016). Carbon footprint of a university in a multiregional model: the case of the University of Castilla-La Mancha. Journal of Cleaner Production, 138, 119-130. https://doi.org/10.1016/j.jclepro.2016.06.009

Greenhouse Gas Calculation Inventory Manual. Retrieved from http://climate.emb.gov.ph/wp-content/uploads/2016/06/GHGManual.pdf (Date accessed: 2020, December 15)

Hong Kong University Carbon Footprint Studies. (2013). Retrieved from http://www.sustainability.hku.hk/report/2011-2013/sustainabilityindicators/carbon (Date accessed: 2020, November 25)

https://data.worldbank.org/indicator/EN.ATM.CO2E.PC $\quad$ (Date accessed: 2020, March 20).

https://ghgprotocol.org/calculation-tools\#cross_sector_tools_id (Date accessed: 2021, March 29).

https://www.unep.org/resources/toolkits-manuals-andguides/greening-universities-toolkit-v20 (Date accessed: 2020, December 21).

Lambrechts, W., \& Liedekerke, L. (2014). Using ecological footprint analysis in higher education: Campusoperations, policy development and educational purposes. Ecological Indicators, 45, 402-406. https://doi.org/10.1016/j.ecolind.2014.04.043

Larsen, H., Pettersen, J., Solli, C., \& Hertwich, E.G. (2013). Investigating the Carbon Footprint of a University - The case of NTNU. Journal of Cleaner Production, 48, 39-47. https:// doi.org/10.1016/j.jclepro.2011.10.007

Li, X., Tan, H., \& Rackes, A. (2015). Carbon footprint analysis of student behavior for a sustainable university campus in China. Journal of Cleaner Production, 106, 7-108. https://doi.org/10.1016/j.jclepro.2014.11.084

Ozawa-Meida, L., Brockway, P., Letten, K., Davies, J., \& Fleming, P.D. (2013). Measuring carbon performance in a UK University through a consumption-based carbon footprint: De Montfort University case study. Journal of Cleaner Production, 56, 185-198. https://doi.org/10.1016/j.jclepro.2011.09.028

Nottingham University Carbon Footprint Studies. (2015). Retrieved from https://www.nottingham.ac.uk/sustainability/carbonmanagement/c arbonmanagement.aspx (Date accessed: 2020, November 25)

Ondokuz Mayıs Üniversitesi (OMÜ), Enerji Yönetimi Yönergesi, (2020). Retrieved from https://s3.omu.edu.tr/kalem/ku655hfkk8hccowcq73vy9r35i42 (Date accessed: 2020, December 25).

Pektaş, İ. (2017). Raylı Ulaşım Sistemleri Sektör Analizi 2017. Anadolu Raylı Ulaşım Sistemleri Kümelenmesi, 71 pp.

Queen University Carbon Footprint Studies. (2015). Retrieved from http://www.queensu.ca/sustainability/campus-initiatives/climateaction/carbon-footprint (Date accessed: 2020, November 25)

Rüşen, S.E., Topçu, M.A., Celep, G. K., Çeltek, S. A., \& Rüşen, A. (2018). Üniversite Kampüs Binaları için Enerji Etüdü: Örnek Çalışma. Çukurova Üniversitesi Mühendislik Mimarlık Fakültesi Dergisi, 33(2), 83-92.

Sreng, R., \& Gümrükçüoğlu Yiğit, M. (2017). Carbon footprint studies on Esentepe Campus of Sakarya University, Turkey in (2015). Sakarya University Journal of Science, 21(5), 1095-1099. https://doi.org/10.16984/saufenbilder.340009 
Tatsanawalai, U. (2015). Carbon Footprint of Environmental Science Students in Suan Sunandha Rajabhat University, Thailand. Procedia Social and Behavioral Sciences, 197, 1156-1160. https://doi.org/10.1016/j.sbspro.2015.07.371

Tokio University Carbon Footprint Studies. (2012). Retrieved from http://www.tscp.u-tokyo.ac.jp/en/about.html (Date accessed: 2020, November 25)

Townsend, J., \& Barrett, J. (2015). Exploring the applications of carbon footprinting towards sustainability at a UK university: reporting and decision making. Journal of Cleaner Production, 107, 164-176. https://doi.org/10.1016/j.jclepro.2013.11.004

Ugle, P., Rao, S., \& Ramachandra, T.V. (2010). Carbon sequestration potential of urban trees. In Proceedings of the Lake 2010: Wetlands, Biodiversity and Climate Change Conference, Bengaluru, India, 22-24 December 2010.

Üreden, A., \& Özden, S. (2018). Kurumsal Karbon Ayak İzi Nasıl Hesaplanır: Teorik Bir Çalışma. Anadolu Orman Araştırmaları Dergisi 4(2), 98-108.

Yaka. I.F., Koçer., A., \& Güngör, A. (2015). Akdeniz University Health Services Vocational Determination of Carbon Footprint. Electronic Journal of Machine Technologies, 12(3), 37-45.

Yañez, P., Sinha, A., \& Vásquez, M. (2020). Carbon Footprint Estimation in a University Campus: Evaluation and Insights. Sustainability, 12, 181. https://doi.org/10.3390/su12010181 